\title{
POLEMIK ANTARA PENERIMAAN DAN PENOLAKAN VAKSINASI KANAK-KANAK: ANALISIS DARI PERSPEKTIF ISLAM
}

\section{Polemics between Acceptance and Rejection of Children's Vaccination: An Analysis from Islamic Perspective}

\author{
Tengku Fatimah Azzahra Tengku Md Fauzi ${ }^{1}$ \\ Noor Fahimah Mohd Razif ${ }^{2}$ \\ Mohd Anuar Ramli ${ }^{3}$
}

\begin{abstract}
The study focuses on the polemic of children vaccination among pro-vax and anti-vax groups. In addition, the study also discusses the use of vaccines against children according to the perspective of Islamic jurisprudence. To achieve that objective, this qualitative study combines library research based on documentation method and field study based on interview methods. The data obtained analyzed its content in a deductive and comparative method.
\end{abstract}

\footnotetext{
1 Postgraduate Student, Department of Fiqh and Usul, Academy of Islamic Studies, University of Malaya, Kuala Lumpur, Malaysia, tengkufatimah1993@gmail.com

2 Senior Lecturer, Department of Fiqh and Usul, Academy of Islamic Studies, University of Malaya, Kuala Lumpur, Malaysia, norfahimah@um.edu.my

3 Senior Lecturer, Department of Fiqh and Usul, Academy of Islamic Studies, University of Malaya, Kuala Lumpur, Malaysia, mohdanuar@um.edu.my
} 
The findings suggest that the Islamic jurisprudence regarding vaccination is necessary. This is because vaccine intake can prevent the risk of infection with vaccine prevention, thus reducing morbidity and mortality rates among children. In this regard, all parties need to get acquainted with the National Immunization Program through the provision of vaccines to children, and even as parents should consider holistic safety without selfishness. The effect of vaccination refusal can pose a risk to other children.

Keywords: immunization, anti-vaccine, maqāṣid al-sharī'ah, mașlahah 'ammah, hifž al-nafs

\section{PENDAHULUAN}

Vaksinasi berjaya mencegah penyakit-penyakit cegahan vaksin di seluruh dunia. Melalui program imunisasi kebangsaan terhadap kanak-kanak yang dijalankan oleh pihak kementerian kesihatan di setiap negara, vaksin berupaya mengurangkan kadar mortaliti dan morbiditi penduduk dunia. Hal ini menunjukkan vaksin yang diberikan sejak usia kanak-kanak mampu mendatangkan kesan jangka masa panjang yang positif kepada jaminan kesihatan yang berpanjangan.

Walau bagaimanapun, penerimaan masyarakat terhadap penggunaan vaksin kepada kanak-kanak mendapat dua reaksi yang berbeza. Terdapat sekelompok masyarakat yang menyokong usaha ini dan terdapat juga golongan yang menolak vaksinasi terhadap kanak-kanak. Kontradiksi pandangan kedua-dua kelompok dalam isu ini telah menimbulkan suatu polemik dalam masyarakat pada hari ini kerana kedua-dua pihak mempunyai hujah dan alasan tersendiri bagi mengukuhkan pendirian masing-masing. ${ }^{4}$ Justeru itu, kajian ini akan menjelaskan berkenaan polemik tentang vaksin kanak-kanak. Fokus perbincangan adalah menjurus kepada kelompok dan hujah kedua-dua golongan yang menyokong dan yang tidak menerima vaksin terhadap kanakkanak.

4 'Golongan Anti-Vaksin Menjerat Anak', laman sesawang Utusan Online, dikemas kini 9 Ogos 2015, dicapai 29 Februari 2016, http://www.utusan.com.my/gayahidup/kesihatan/golongan-antivaksin-menjerat-anak-1.122355. Lihat juga Khoo Yoon Khean, 'Gerakan Anti-Vaksin Keliru Fakta Sebenar,' laman sesawang The Malaysian Medical Gazatte, dikemas kini 5 Disember 2013, dicapai 29 Februari 2016, http://www.mmgazette.com/gerakan-anti-vaksin-keliru-fakta-sebenar-drkhoo-yoong-khean. 


\section{PERKEMBANGAN VAKSINASI KANAK-KANAK DI MALAYSIA}

Vaksinasi di Malaysia dilaksanakan menerusi Program Imunisasi Kebangsaan atau National Immunisation Programme (NIP) yang diperkenalkan pada 1950-an. ${ }^{5}$ Malaysia sebagai sebuah negara membangun menyahut saranan Pertubuhan Kesihatan Sedunia (WHO) untuk memperkasakan Expanded Programme on Immunisation (EPI). Program imunisasi ini adalah bertujuan untuk mencegah penyakit-penyakit cegahan vaksin seperti polio, difteria, tetanus, pertusis, campak (measles), hepatitis B dan tuberkulosis di seluruh negara. ${ }^{6}$

Pelaksanaan Program Imunisasi Kebangsaan di Malaysia bermula apabila diperkenalkan dengan vaksin smallpox pada tahun $1950 .{ }^{7}$ Kemudian, imunisasi diteruskan dengan pemberian vaksin DPT (Diphteria, Pertussis, Tetanus) pada tahun 1960. Program ini diikuti dengan pemberian vaksin BCG (Bacille Calmette-Guerin) untuk mencegah tuberkulosis pada tahun 1961 dan vaksin OPV (Oral Polio Vaccine) iaitu vaksin yang dititis ke dalam mulut pada tahun 1972 untuk mencegah penyakit polio. Pada tahun 1984, imunisasi melalui pemberian vaksin campak diperkenalkan dan diteruskan dengan vaksin rubela pada tahun 1988. Manakala vaksin hepatitis B dilaksanakan pada tahun berikutnya iaitu pada $1989 .{ }^{8}$ Imunisasi DPT kemudiannya digabungkan dengan imunisasi Hib iaitu vaksin yang mencegah penyakit haemophilus influenza jenis B pada tahun 2002. ${ }^{9}$ Seterusnya, tambahan vaksin untuk penyakit beguk (mumps) digabungkan dalam vaksin MMR (measles, mumps, rubella) yang juga dilaksanakan pada tahun 2002. ${ }^{10}$

5 'Soalan Lazim Mengenai Vaksin dan Imunisasi,' dikemas kini Julai 2015, dicapai 28 September 2015, http://www.moh.gov.my

6 Clinical Practice Guidelines: Childhood Immunisation, Ministry of Health Malaysia and Academy of Medicine, (MOH/P/PAK/81.04 (GU) (2004), 1, http:// www.moh.gov.my/attachments/3934.pdf

7 'National Pharmacy News: Immunisation for The Good of All,' laman sesawang Persatuan Farmasi Malaysia, dikemas kini 26 Mei 2002, dicapai 5 Jun 2017, http:// www.mps.org.my/newsmaster.cfm?\&menuid=36\&action=view\&retrieveid=196.

8 Clinical Practice Guidelines: Childhood Immunisation, Ministry of Health Malaysia and Academy of Medicine, (MOH/P/PAK/81.04 (GU) (2004), 1-2, http://www.moh.gov.my/attachments/3934.pdf

9 Bahagian Pendidikan Kesihatan, Kementerian Kesihatan Malaysia, 'Fakta Imunisasi Kanak-Kanak Bagi Kakitangan Kesihatan,' 10, http://www.infosihat. gov.my/infosihat/media/garis_panduan/I/pdf/03_imunisasiKanak_BM.pdf.

10 Bahagian Pendidikan Kesihatan, Kementerian Kesihatan Malaysia, 'Fakta Imunisasi Kanak-Kanak Bagi Kakitangan Kesihatan.' 
Secara umumnya, terdapat 11 jenis vaksin yang diberikan secara percuma kepada bayi dan kanak-kanak di Malaysia yang berumur 18 bulan ke bawah melalui Program Imunisasi Kebangsaan di bawah Kementerian Kesihatan Malaysia. ${ }^{11}$ Antaranya ialah vaksin BCG bagi mencegah penyakit tuberkulosis, vaksin hepatitis B, vaksin DTaP, gabungan vaksin yang melindungi daripada penyakit difteria, tetanus dan pertusis, vaksin polio bagi menghalang penyakit poliomyelitis, vaksin Hib bagi cegahan penyakit Haemophilus influenza jenis $\mathrm{B}$, vaksin MMR yang menggabung vaksin bagi penyakit measles, mumps dan rubela. Manakala satu vaksin diberikan khusus untuk penduduk di Sarawak iaitu vaksin JE yang mencegah penyakit Japanese encephalitis.

Selain itu, terdapat beberapa jenis vaksin tambahan disediakan kepada bayi dan kanak-kanak dalam lingkungan umur sembilan tahun ke bawah. Antaranya ialah vaksin untuk penyakit rotavirus, pneumokokal, influenza, hepatitis A, varicella atau demam cacar air, demam tifoid, kolera dan meningokokal. ${ }^{12}$ Vaksin-vaksin ini boleh didapati di mana-mana hospital dan klinik swasta memandangkan KKM tidak membekalkan vaksin-vaksin ini secara percuma. Hal ini kerana vaksin tambahan ini hanyalah sebagai usaha untuk meningkatkan perlindungan kepada kanak-kanak dan sebagai langkah berjaga-jaga sekiranya wabak penyakit berkenaan melanda. Walau bagaimanapun, vaksin-vaksin yang terdapat dalam jadual Program Imunisasi Kebangsaan sudah memadai sebagai perlindungan menyeluruh terhadap bayi dan kanak-kanak di Malaysia. ${ }^{13}$ Oleh sebab itu, para ibu bapa hendaklah memastikan pengambilan vaksin percuma oleh KKM perlu mengikut jadual yang ditetapkan bagi memastikan perlindungan kesihatan terhadap anak-anak lebih terjamin.

\section{POLEMIK VAKSINASI KANAK-KANAK}

\section{PANDANGAN YANG MENYOKONG}

Kelompok masyarakat yang menyokong vaksinasi adalah terdiri daripada beberapa golongan. Mereka yang dimaksudkan ini adalah termasuk juga dalam kalangan komuniti di Malaysia. Antaranya ialah golongan yang bekerja dalam sektor kesihatan. ${ }^{14}$ Kebiasaannya, mereka terlibat secara langsung dalam usaha

11 Immunise4life Expert Coalition, Immunise4life Booklet (Selangor: Ultra Work Coomunications), 12.

12 Immunise4life Expert Coalition, Immunise4life Booklet, 13.

13 Immunise4life Expert Coalition, Immunise4life Booklet, 10.

14 Afiq Izzudin A Rahim (Pegawai Perubatan dan Kesihatan, Klinik Kesihatan Badang, Kota Bharu, Kelantan), dalam temu bual dengan penulis melalui emel, 3 Ogos 2016. 
vaksinasi yang dijalankan seperti pegawai perubatan, kakitangan kesihatan, penyelidik dalam bidang imunologi, dan institusi kesihatan kerajaan serta organisasi bukan kerajaan.

Bahkan, mereka yang mempunyai tahap pendidikan yang baik dan kebiasaannya terdiri daripada masyarakat kelas pertengahan dan ke atas adalah lebih cenderung untuk menyokong vaksinasi. ${ }^{15}$ Ini kerana tahap pendidikan turut mempengaruhi seseorang daripada aspek keterbukaan untuk menerima kepelbagaian pendapat. Walaupun begitu, adunan maklumat tersebut bukan sekadar dicedok begitu sahaja, tetapi diterima berdasarkan hujah dan secara rasional.

Kebiasaannya mereka juga merupakan orang awam atau golongan bawahan ${ }^{16}$ yang mempunyai kepercayaan yang tinggi terhadap polisi kerajaan. Mereka yakin bahawa program imunisasi yang dijalankan oleh pihak kerajaan mampu melindungi kesihatan anak-anak mereka untuk masa-masa mendatang. Menurut Salmon et al., 35 peratus daripada ibu bapa meletakkan keyakinan yang penuh terhadap kerajaan dalam usaha imunisasi berbanding 24 peratus ibu bapa yang tidak menyokong usaha tersebut. ${ }^{17}$

Bukan itu sahaja, malahan golongan ibu bapa yang pernah mempunyai pengalaman dalam isu ini berkemungkinan besar turut menyatakan sokongan terhadap usaha vaksinasi ini. Ini kerana pengalaman seseorang jelas mempengaruhi setiap tindak-tanduk dalam kehidupan, sama ada ingin mengulangi pengalaman sama atau mengelakkannya. Kebiasaannya, mereka mempunyai anak-anak yang pernah berpengalaman mendapat komplikasi penyakit dan masalah kesihatan ${ }^{18}$, maka dengan sebab itu, pengalaman mengajar mereka untuk mencari suatu solusi yang lebih baik bagi mengelakkan perkara yang sama berulang.

Begitu juga, penggunaan vaksin turut disokong oleh para ilmuan dan pertubuhan Islam di seluruh dunia. Antara tokoh ilmuan Islam yang bersetuju

15 Afiq Izzudin A Rahim (Pegawai Perubatan dan Kesihatan, Klinik Kesihatan Badang, Kota Bharu, Kelantan), dalam temu bual dengan penulis melalui emel, 3 Ogos 2016

16 Afiq Izzudin A Rahim (Pegawai Perubatan dan Kesihatan, Klinik Kesihatan Badang, Kota Bharu, Kelantan), dalam temu bual dengan penulis melalui emel, 3 Ogos 2016.

17 Archana Chatterjee (ed.), Vaccinophobia and Vaccine Controversies of the 21st Century, 102.

18 Afiq Izzudin A Rahim (Pegawai Perubatan dan Kesihatan, Klinik Kesihatan Badang, Kota Bharu, Kelantan), dalam temu bual dengan penulis melalui emel, 3 Ogos 2016. 
dengan usaha vaksinasi ialah Muhammad Ṭanțāwi, Imam Besar Masjid alAzhar; 'Ali Jum'ah, Mufti Besar Mesir; Yūsuf al-Qaraḍāwi, Ketua Kesatuan Ulama Muslimin Sedunia dan 'Abd al-'Azīz bin Bāz, Mufti Besar Saudi Arabia. Perkara ini dinyatakan oleh para ulama tersebut melalui fatwa mereka berkenaan keharusan vaksin kepada kanak-kanak berdasarkan penilaian hujah menurut perspektif Islam. Bahkan, perkara ini turut disokong penuh oleh beberapa pertubuhan Islam seperti Darul Ulum Deoband di India, Pertubuhan Persidangan Islam, Kesatuan Ulama Sedunia dan Majlis Ulama Indonesia. ${ }^{19}$

Malahan, kelompok yang menyokong vaksinasi turut terdiri daripada organisasi kesihatan kerajaan seperti yang terdapat di Malaysia iaitu Kementerian Kesihatan Malaysia (KKM) dan pelbagai organisasi kesihatan bukan kerajaan seperti UNICEF Malaysia, Immunise4Life, Medical Myth Buster dan Persatuan Paedatrik Kanak-Kanak Malaysia. Bahkan, vaksinasi turut disokong oleh institusi agama kerajaan seperti Jabatan Kemajuan Islam Malaysia (JAKIM), majlis agama di setiap negeri, dan institusi agama bukan kerajaan.

\section{HUJAH BAGI KELOMPOK YANG MENYOKONG VAKSIN}

Kelompok masyarakat yang menyokong vaksin turut mendatangkan beberapa hujah penerimaan vaksin. Menurut mereka, vaksin dapat mencegah daripada penyakit cegahan vaksin, mengurangkan kadar kematian penduduk dan menjamin imuniti berkelompok atau herd immunity. Bahkan, dengan adanya vaksin halal sebagai alternatif, mereka lebih yakin untuk mengambil suntikan vaksin. Apatah lagi, perubatan melalui vaksin lebih menjimatkan kos. Oleh sebab itu, hujah-hujah ini menguatkan lagi pandangan kelompok yang menyokong vaksin. Hujah-hujah ini akan dijelaskan dengan lebih terperinci berdasarkan sub topik berikutnya.

\section{Hujah 1: Vaksin mencegah daripada penyakit cegahan vaksin}

Masyarakat memilih untuk mengambil suntikan vaksin sebagai pelan perlindungan keluarga mereka kerana didasari oleh beberapa hujah. Antara hujah yang dikemukakan ialah vaksin dapat mencegah daripada penyakit cegahan vaksin seperti batuk kokol, kancing gigi, hepatitis B, campak, difteria, rubela dan poliomyelitis. Ibu bapa yang menyokong vaksin menyedari hakikat bahawa vaksin dapat melindungi anak-anak mereka daripada penyakit-penyakit tersebut. Lebih-lebih lagi apabila berlaku kebimbangan dan kegusaran mereka

19 Fatima Riaz \& Yasir Waheed, 'Islam dan Polio,' The Lancet Infectious Disease, 14/9 (September 2014), 791-792. 
terhadap bakteria asing dan berbahaya yang akan menyerang tubuh badan anak-anak sekiranya mereka tidak memilih pakej suntikan vaksin sebagai langkah pencegahan daripada penyakit-penyakit tersebut. ${ }^{20}$ Bahkan, sejarah perubatan telah membuktikan secara klinikal keberkesanan vaksin sebagai perubatan pencegahan terhadap penyakit cegahan vaksin di peringkat global. Buktinya ialah pembasmian penyakit smallpox pada tahun 1980 hasil daripada pemberian vaksin smallpox sehingga menyebabkan penyakit tersebut sudah pupus sehingga ke hari ini. ${ }^{21}$ Begitu juga, sejak awal diperkenalkan vaksin polio oleh WHO pada 1988, penyakit tersebut telah hampir dibasmikan secara keseluruhan. ${ }^{22}$ Malahan, pelbagai risiko penyakit cegahan vaksin dapat dikurangkan melalui program vaksinasi. Tambahan pula, dengan adanya sistem pengawalan kejadian pasca imunisasi, segala kes yang tidak diingini berlaku selepas proses vaksinasi dapat dipantau dan diurus baik oleh pihak yang terlibat. ${ }^{23}$ Justeru itu, mereka yang menerima usaha vaksinasi meyakini manfaat besar vaksin dalam mengurangkan risiko jangkitan penyakit-penyakit yang berbahaya.

\section{Hujah 2: Vaksin mengurangkan kadar kematian penduduk}

Selain itu, masyarakat yang menerima vaksinasi juga memperakui bahawa vaksin berupaya mengurangkan kadar kematian dalam sesebuah kelompok masyarakat. Pengabaian pengambilan vaksin bukan sahaja menyebabkan risiko penyakit cegahan vaksin menyerang manusia, tetapi perkara itu juga boleh membawa kepada kematian. ${ }^{24}$ Penyakit cegahan vaksin sepatutnya tidak boleh dipandang enteng oleh sesetengah individu, terutamanya kepada golongan kanak-kanak yang mempunyai tahap imuniti badan yang masih lemah. Hal ini kerana, dalam beberapa kemungkinan, sistem imuniti badan manusia gagal melawan serangan penyakit tersebut jika tiada pencegahan awal melalui suntikan vaksin. Kesannya, penyakit berjaya menyerang, bahkan boleh membawa maut. Beberapa kes sudah dilaporkan menunjukkan bahawa

20 Julie Leask et al., 'What Maintains Parental Support for Vaccination When Challenged by Anti-Vaccination Messages? A Qualitative Study,' Vaccine, 24/4950 (2006), 7238-7245.

21 Philip D. Minor, 'Live Attenuated Vaccines: Historical Successes and Current Challenges,' Virology 479-480 (2015): 379-392.

22 Philip D. Minor, 'Live Attenuated Vaccines: Historical Successes and Current Challenges,' 379-392.

23 Philip D. Minor, 'Live Attenuated Vaccines: Historical Successes and Current Challenges,' 379-392.

24 Susanna Esposito et al., "Vaccine-Preventable Diseases: From Paediatric to Adult Targets,' European Journal of Internal Medicine, 25/3 (2014) 203-212. 
pengabaian vaksin boleh mendatangkan implikasi yang sangat besar kepada manusia. ${ }^{25}$ Oleh sebab itu, memilih untuk mengambil suntikan vaksin adalah salah satu cara untuk mengurangkan kadar kematian penduduk dunia.

\section{Hujah 3: Vaksin menjamin herd immunity}

Begitu juga, seseorang individu yang mengambil suntikan vaksin diibaratkan menjaga satu komuniti. Kebaikan vaksin sebenarnya turut dirasai oleh seluruh anggota masyarakat. Ini kerana vaksin bukan sahaja melindungi diri individu tersebut, tetapi dapat mengurangkan risiko penyebaran penyakit cegahan vaksin kepada orang sekeliling. ${ }^{26}$ Apatah lagi, kesan perlindungan vaksin dapat dimanfaatkan juga kepada kelompok masyarakat yang mempunyai halangan untuk mendapatkan suntikan vaksin seperti bayi pra-matang, wanita hamil dan mereka yang mempunyai sistem imuniti badan yang tidak dapat bertindak balas dengan vaksin secara sempurna. ${ }^{27}$ Konsep ini dinamakan sebagai imuniti berkelompok atau herd immunity. Oleh sebab itu, tindakan memastikan setiap individu mendapat imunisasi bukan terletak di bahu ibu bapa semata-mata, tetapi termasuk dalam tanggungjawab seluruh anggota masyarakat.

\section{Hujah 4: Wujud vaksin halal sebagai alternatif}

Selain itu, antara hujah yang menjadi sokongan kepada pengguna beragama Islam khususnya ialah wujudnya vaksin halal di pasaran Malaysia. ${ }^{28}$ Antara perkara yang menjadi kebimbangan dalam kalangan pengguna Muslim adalah perkara yang melibatkan halal haram sesuatu produk, sama ada dalam aspek pemakanan, perubatan, pemakaian dan perindustrian. Kegusaran inilah yang membawa kepada keraguan untuk menggunakan sesuatu produk. Walau bagaimanapun, isu ini tidak menjadi suatu kebimbangan dalam kalangan penyokong vaksinasi di Malaysia. Hal ini kerana jaminan yang diberikan oleh KKM dan JAKIM bahawa vaksin terhadap kanak-kanak yang diguna

25 'Kenyataan Akhbar KPK 5 Jan 2016: Kes Difteria di Malaysia,' dikemas kini 5 Januari 2016, dicapai 29 Februari 2016, http://kpkesihatan.com/2016/01/05/ kenyataan-akhbar-kpk-5-jan-2016-kes-difteria-di-malaysia.

26 Julie Leask et al., 'What Maintains Parental Support for Vaccination When Challenged by Anti-Vaccination Messages? A Qualitative Study'.

27 Carmen Liliana Barbacariu, 'Parents' Refusal to Vaccinate Their Children: An Increasing Social Phenomenon Which Threatens Public Health,' Procedia - Social and Behavioral Sciences 149 (2014), 84-91.

28 'Tiada DNA Babi: KKM Jamin Semua Vaksin di Malaysia Halal,' dikemas kini 2 November 2015, dicapai 12 Ogos 2016, http://www.mynewshub.cc/2015/11/02/ tiada-dna-babi-kkm-jamin-semua-vaksin-di-malaysia-halal. 
pakai di Malaysia adalah dibenarkan untuk umat Islam. ${ }^{29}$ Bahkan, kenyataan berkaitan keharusan vaksin oleh golongan agamawan menguatkan lagi hujah penerimaan vaksin di Malaysia. ${ }^{30}$

\section{PANDANGAN YANG MENOLAK}

Secara umumnya, golongan yang menolak vaksin boleh dikategorikan kepada dua jenis. Pertama, kumpulan yang disebut sebagai vaccine refusal. Mereka ialah masyarakat yang sangat tegar menolak vaksin. Mereka berusaha mendatangkan pelbagai sebab dan dakwaan kerana ingin mengelakkan anakanak mereka mendapat suntikan vaksin. Antara dakwaan mereka yang utama adalah berkenaan status halal haram vaksin. Seterusnya, kumpulan kedua pula dikenali sebagai vaccine hesitancy. Kebiasaannya, mereka tidaklah seratus peratus menolak vaksin dan tidaklah begitu tegar menolak vaksin. Namun begitu, mereka tidak mengambil vaksin atas beberapa faktor teknikal seperti isu kekangan masa, kurang kemudahan pengangkutan atau kekangan kewangan. Masyarakat dalam kumpulan kedua lebih bersifat atas pagar terhadap vaksin dan masih boleh diubah pendirian mereka. Sebaliknya, kumpulan pertama agak sukar dirombak pegangan mereka melainkan melalui tindakan tegas oleh pihak berautoriti. Kelompok ini menjadi fokus perbincangan pengkaji.

Secara lebih khusus, golongan yang menolak vaksin iaitu refusal group boleh diklasifikasikan kepada beberapa kelompok masyarakat. Walaupun penjelasan kelompok ini meliputi masyarakat umum di peringkat global, namun begitu mereka yang dimaksudkan ini juga terdiri dalam kalangan masyarakat yang menolak vaksin di Malaysia. Pertama, kelompok yang berlatarbelakangkan pendidikan agama yang kurang mendapat pendedahan atau penjelasan daripada pihak berautoriti. ${ }^{31}$ Ini kerana sebahagian mereka agak sukar menerima penggunaan sesuatu produk yang berasal daripada

29 Irwan Mohd Subri, 'Pencegahan Penyakit Melalui Kaedah Pelalian Menurut Perspektif Islam,' 'Ulum Islamiyyah Journal 17 (2016), 57-77. Lihat juga 'Kementerian Kesihatan Jamin Vaksin di Malaysia Halal,' dikemas kini 29 Oktober 2015, dicapai 16 Ogos 2016, http://www.mstar.com.my/berita/beritasemasa/2015/10/29/kementerian-kesihatan-jamin-vaksin-di-malaysia-halal/.

30 Vaksin Halal: Rakyat Diminta Tidak Ragu-Ragu Ambil Suntikan Imunisasi,' dikemas kini 11 Julai 2016, dicapai 16 Ogos 2016, http://www.astroawani.com/ berita-malaysia/vaksin-halal-rakyat-diminta-tidak-ragu-ragu-ambil-suntikanimunisasi-110703.

31 Afiq Izzudin A Rahim (Pegawai Perubatan dan Kesihatan, Klinik Kesihatan Badang, Kota Bharu, Kelantan), dalam temu bual dengan penulis melalui emel, 3 Ogos 2016. 
Barat sebagai langkah waspada bagi mengelakkan bahan yang diragui status halal dan kesuciannya. Sebaliknya, mereka lebih menggemari rawatan yang dilihat lebih selamat dan meyakinkan seperti pengamalan penjagaan kesihatan menurut sunnah dan rawatan alternatif seperti homeopati. ${ }^{32}$ Bahkan, kesan kurang pendedahan berkenaan vaksin secara mendalam membuatkan mereka merasakan vaksin bukan suatu keperluan utama yang perlu dititikberatkan kepada anak-anak memandangkan mereka sudah sebati dengan kaedah perubatan yang dilihat lebih mesra pengguna Islam.

Selain itu, amalan turun-menurun keluarga seseorang secara tidak langsung turut mempengaruhi pendiriannya terhadap vaksin. Seseorang yang datang daripada keluarga yang sememangnya menolak ubat-ubatan konvensional dilihat lebih cenderung untuk menolak vaksin untuk anak-anak mereka. Bagi kelompok ini, ubat-ubatan di hospital bukanlah menjadi keutamaan dalam keluarga mereka. Oleh sebab itu, sebahagian mereka memilih untuk menolak atas sebab-sebab tersendiri yang sudah menjadi pegangan tradisi keluarga. ${ }^{33}$

Seterusnya, kelompok ini juga terdiri daripada mereka yang mempunyai public of interest atau kepentingan tertentu terhadap orang lain. Antaranya ialah peniaga produk kesihatan, pengamal perubatan alternatif dan para peniaga makanan sunnah. ${ }^{34}$ Mereka menggunakan testimoni kebaikan produkproduk tersebut untuk melariskan hasil jualan, termasuklah mendakwa produk tersebut mampu mencegah beberapa penyakit yang sebenarnya hanya boleh dicegah oleh vaksin.

Begitu juga, terdapat ibu bapa yang menolak vaksin kerana anak-anak mereka pernah mengalami masalah atau komplikasi akibat penyakit semasa menjalankan rawatan di pusat kesihatan. ${ }^{35}$ Walaupun sebenarnya kesan sampingan yang diperoleh anak-anak mereka bukanlah berpunca daripada vaksin, tetapi pengalaman yang dilalui telah menimbulkan trauma dan menyebabkan mereka enggan untuk mengambil apa-apa rawatan di pusat kesihatan termasuklah suntikan vaksin.

Di samping itu, golongan atas pagar atau symphatizer juga boleh tergolong sebagai salah satu kelompok yang menolak vaksin. Pada permulaannya,

32 Suhaimi (seorang anti-vax), dalam temu bual dengan penulis, 27 September 2016.

33 Suhaimi (seorang anti-vax), dalam temu bual dengan penulis, 27 September 2016.

34 Afiq Izzudin A Rahim (Pegawai Perubatan dan Kesihatan, Klinik Kesihatan Badang, Kota Bharu, Kelantan), dalam temu bual dengan penulis melalui emel, 3 Ogos 2016.

35 Afiq Izzudin A Rahim (Pegawai Perubatan dan Kesihatan, Klinik Kesihatan Badang, Kota Bharu, Kelantan), dalam temu bual dengan penulis melalui emel, 3 Ogos 2016. 
golongan ini hanya menjadi pemerhati di media sosial yang hanya mengikuti perkembangan gerakan yang menolak vaksin. Walau bagaimanapun, selepas membaca maklumat yang kurang kesahihannya di media sosial atau laman sesawang, akhirnya mereka terpengaruh dan turut menyokong apa yang dibawa oleh kelompok yang tegar menolak vaksin. ${ }^{36}$ Ini kerana kebanyakan dakwaan salah tentang vaksin disebarkan secara halus mahupun terang-terangan di media massa elektronik, selain dibincangkan dalam seminar-seminar yang dianjurkan oleh kelompok mereka.

Golongan ini bukan sahaja dalam kalangan orang awam, tetapi terdiri juga daripada golongan profesional. Bahkan terdapat sebilangan mereka yang mempunyai latar belakang dalam bidang perubatan dan kajian saintifik. ${ }^{37}$ Walaupun mereka arif tentang ilmu perubatan, tetapi disebabkan mempunyai kepentingan tertentu, pendirian mereka turut cenderung untuk menidakkan kebaikan vaksin.

Selain itu, kebanyakan golongan ini adalah mereka yang menolak kaedah saintifik dan rujukan yang berwasit. ${ }^{38}$ Mereka lebih cenderung untuk mengambil pendapat yang menepati pendirian mereka sekalipun pandangan tersebut tidak didasari dengan fakta yang kukuh. Bahkan, golongan ini seringkali menafikan kaedah dan hasil kajian saintifik yang bersifat umum. Oleh sebab itu, mereka banyak memetik hujah tokoh anti vaksin yang sememangnya telah terbukti mengabaikan kaedah saintifik yang betul. Namun begitu, pada masa yang sama mereka mengkehendaki keabsahan saintifik terhadap teori-teori bahawa vaksin adalah berbahaya. ${ }^{39}$ Implikasinya, hujah golongan ini dilihat seakanakan berakar umbikan kajian saintifik, tetapi sebenarnya hanyalah bersifat pseudosains.

Begitu juga, di sesetengah negara, kelompok yang menolak vaksin dikaitkan dengan para ekstremis agama Kristian. Mereka mendakwa bahawa penyakit datang daripada tuhan, justeru tuhan yang berhak menyembuhkan penyakit. Manakala manusia tidak bertanggungjawab dalam sebarang urusan penyakit.

36 Afiq Izzudin A Rahim (Pegawai Perubatan dan Kesihatan, Klinik Kesihatan Badang, Kota Bharu, Kelantan), dalam temu bual dengan penulis melalui emel, 3 Ogos 2016.

37 Julie Leask and Peter McIntyre, 'Public Opponents of Vaccination: A Case Study,' Vaccine, 21/32 (2003), 4700-4703.

38 Gregory A. Poland, 'The Clinician's Guide to the Anti-Vaccinationists' Galaxy'.

39 Anna Kata, 'A Postmodern Pandora's box: Anti-Vaccination Misinformation on the Internet,' Vaccine 28/7 (2010): 1709--1716. 
Oleh sebab itu mereka menolak vaksin kerana dianggap mencampuri urusan tuhan mereka. ${ }^{40}$

Dalam aspek psikologi, terdapat sebahagian ibu bapa yang cenderung kepada sentimen yang dibawa oleh golongan yang tegar menolak vaksin adalah kerana dipengaruhi oleh pendirian yang salah terhadap vaksin. ${ }^{41}$ Dalam hal ini mereka lebih cenderung untuk menjadikan pengalaman orang sebelum ini sebagai sandaran dalam membuat keputusan terhadap vaksin kepada anak-anak mereka. Sebagai contohnya, terdapat sebilangan ibu bapa yang berkongsi gambar dan bukti yang menzahirkan kesan sampingan negatif vaksin yang menimpa anakanak mereka di media sosial. Rentetan itu, informasi ini menyebabkan para ibu bapa yang lain tersalah anggap bahawa vaksinlah punca utama masalah tersebut berlaku. Walhal, kajian saintifik telah membuktikan bahawa kejadian pasca imunisasi bukanlah seratus peratus berpunca daripada suntikan vaksin. Oleh sebab itu, kesan psikologi memberi kesan dalam mempengaruhi tindakan mereka yang menolak vaksin. Mereka lebih berpaksikan realiti pengalaman orang lain yang sebenarnya berbeza dalam pelbagai aspek berbanding dengan bukti dan fakta daripada kajian saintifik yang telah dijalankan. ${ }^{42}$

Di Malaysia, kebanyakan mereka yang menolak vaksin lebih gemar menggelarkan diri mereka sebagai golongan pro-choice berbanding anti vaksin. Hal ini kerana, prinsip mereka bukanlah untuk menghalang program vaksinasi dijalankan atau melarang suntikan vaksin, tetapi mereka memperjuangkan ketelusan dalam menyebarkan maklumat berkenaan kejadian pasca imunisasi (AEFI) dan Garis Panduan Farmakovigilan (GPF). ${ }^{43}$ Oleh yang demikian, harapan mereka, masyarakat boleh menilai dan membuat keputusan yang terbaik untuk anak-anak.

\section{HUJAH BAGI KELOMPOK YANG MENOLAK VAKSIN}

Asasnya, masyarakat yang menolak vaksin juga mempunyai pelbagai hujah untuk menguatkan pandangan mereka terhadap vaksin. Antaranya, mereka mendakwa vaksin boleh mendatangkan kesan sampingan yang memudaratkan, vaksin yang digunakan adalah tidak halal dan penggunaan vaksin turut

40 Pieter H. Streefland, 'Public Doubts About Vaccination Safety and Resistance Against Vaccination'.

41 Robert M. Wolfe, Lisa K. Sharp, Martin S. Lipsky, ' Content and Design Attributes of Antivaccination Web Sites,' JAMA 287/24 (2002): 3245-3248.

42 Robert M. Wolfe, Lisa K. Sharp, Martin S. Lipsky, 'Content and Design Attributes of Antivaccination Web Sites,' 3245-3248.

43 Laman Facebook salah seorang yang menolak vaksin, dikemas kini 22 Mei 2015, dicapai 16 Ogos 2016, https://www.facebook.com/ain.naurah/ posts/10207253217034423. 
dilarang oleh sesetengah agama. Selain itu, mereka juga mendakwa bahawa vaksin merupakan teori konspirasi bagi merosakkan umat Islam. Malahan, pengamalan perubatan sunnah dan rawatan alternatif dikatakan lebih baik bagi menggantikan penggunaan vaksin. Perincian hujah bagi kelompok ini akan dijelaskan dalam sub topik seterusnya.

\section{Hujah 1: Kesan sampingan yang memudaratkan}

Antara hujah yang diberikan oleh golongan yang menolak vaksin ialah vaksin boleh membahayakan kesihatan badan. ${ }^{44}$ Mereka berpendapat bahawa kandungan vaksin boleh menyebabkan penyakit lain yang lebih serius. Antara dakwaan tersebut ialah vaksin mengandungi bahan yang berbahaya seperti thimerosal yang boleh menyebabkan autisme. ${ }^{45}$ Dakwaan ini menjadi kontroversi apabila seorang pengkaji bernama Andrew Wakefield mendedahkan pemberian vaksin MMR yang mencegah penyakit campak, beguk dan rubela mempunyai kaitan dengan autisme. ${ }^{46}$ Walaupun kajian saintifik telah membuktikan vaksin tersebut sebenarnya tidak berkait dengan autisme, namun begitu kenyataan Wakefield ini telah menjadi sandaran kuat bagi golongan yang menolak vaksin. ${ }^{47}$ Begitu juga, dakwaan yang mengatakan bahawa vaksin adalah beracun dan boleh mengakibatkan penyakit idiopatik yang berpunca daripada bahan-bahan beracun dalam vaksin termasuklah bahan anti beku, eter, formaldehid, merkuri dan nanobakteria. ${ }^{48}$ Antara penyakit idiopatik yang menjadi kebimbangan ibu bapa kesan daripada vaksin ialah autisme, sindrom bayi mati mengejut (SIDS), ${ }^{49}$ sawan, ${ }^{50}$ imun tidak berfungsi, diabetes, penyakit

44 Archana Chatterjee (ed.), Vaccinophobia and Vaccine Controversies of the 21st Century, 102.

45 Archana Chatterjee (ed.), Vaccinophobia and Vaccine Controversies of the 21st Century, 102.

46 Suhazeli Abdullah, Vaksin untuk Bayi Anda: Mitos vs Realiti (Kelantan: Koperasi Amal Medik Malaysia Bhd., 2014), 29.

47 Katrina F. Brown, 'UK parents' decision-making about measles-mumps-rubella (MMR) vaccine 10 years after the MMR-autism controversy: A qualitative analysis,' Vaccine, 30/10 (2012): 1855-1864.

48 Anna Kata, 'A Postmodern Pandora's box: Anti-Vaccination Misinformation on the Internet.'

49 'Anti Vaksin,' laman Facebook salah seorang yang menolak vaksin, dikemas kini 23 Oktober 2015, dicapai 16 Ogos 2016, https://www.facebook.com/ain.naurah/ posts/10208462951397026.

50 'Anti Vaksin,' laman Facebook. 
neurologik, penyakit mental, ${ }^{51}$ dan penyakit atopik termasuklah alahan pada rinitis, ekzema dan asma. ${ }^{52}$ Bahkan, vaksin tiga dan lima serangkai yang diguna pakai di Malaysia dikatakan memburukkan lagi keadaan kanak-kanak dengan komplikasi jangkitan paru-paru, jangkitan dalam darah serta risiko penyakit autoimun. ${ }^{53}$

Begitu juga, vaksin dibimbangi akan membebankan sistem imuniti badan kanak-kanak dengan lambakan antigen yang banyak. ${ }^{54}$ Beban yang berlebihan pada antigen berlaku apabila tubuh manusia tidak berupaya untuk memberi tindak balas dengan selamat terhadap antigen vaksin yang masuk ke dalam badan dengan kuantiti yang banyak. Implikasinya, suntikan vaksin yang kerap dianggap akan semakin melemahkan sistem imuniti badan kanak-kanak. Apatah lagi, tiada data yang jelas dan meyakinkan berkenaan reaksi sistem imuniti bayi pra matang terhadap vaksin. Ini kerana sistem imuniti bayi sendiri masih belum cukup matang dan perlu bergantung kepada bantuan antibodi daripada darah ibunya melalui saluran tali pusat dan susu ibu. ${ }^{55}$ Oleh sebab tu, kelompok ini lebih memilih untuk anak-anak melalui proses imuniti secara semulajadi, berbanding mendapatkannya menerusi vaksin. Kaedah ini dilihat lebih selamat, sementelah dos vaksin yang banyak itu juga belum tentu berkesan sepenuhnya terhadap kesihatan kanak-kanak. ${ }^{56}$

\section{Hujah 2: Vaksin tidak halal}

Mereka yang menolak vaksin turut menggunakan hujah yang berkaitan keagamaan bagi mengukuhkan pandangan mereka. Dalam hal ini mereka mendakwa vaksin dihasilkan daripada bahan-bahan yang bersifat najis, tidak

51 'Elakkan Imunisasi,' laman sesawang salah seorang yang menolak vaksin, dikemas kini 4 November 2012, dicapai 16 Ogos 2016, http://zullgp.blogspot.my/2012/11/ elakkan-suntikan-imunisasi.html.

52 Robert M. Wolfe, Lisa K. Sharp, Martin S. Lipsky,' Content and Design Attributes of Antivaccination Web Sites'.

53 'Anti Vaksin,' laman Facebook salah seorang yang menolak vaksin.

54 Archana Chatterjee (ed.), Vaccinophobia and Vaccine Controversies of the 21st Century, 102.

55 'Whats Wrong with Vaccination,' laman sesawang salah seorang yang menolak vaksin, dikemas kini 23 Disember 2013, dicapai 12 Ogos 2016, http://ourkizuna. blogspot.my/2013/09/whats-wrong-with-vaccination.html.

56 Anna Kata, 'Anti-Vaccine Activists, Web 2.0, and The Postmodern Paradigm:- An Overview of Tactics and Tropes Used Online by The Anti-Vaccination Movement,' Vaccine 30/25 (2012): 3778-3789.- 
suci dan diragui status halalnya. ${ }^{57}$ Puncanya ialah proses vaksin menggunakan bahan yang diperbuat daripada babi seperti gelatin, ${ }^{58}$ enzim daripada babi, nanah serta organ haiwan seperti kera dan kuda. ${ }^{59}$ Bahkan, pengambilan vaksin yang mengandungi kandungan asid amino daripada babi juga adalah haram. ${ }^{60}$ Bahkan, sebahagiannya turut mendakwa bahawa walaupun vaksin sudah melalui proses pengasingan, namun masih terdapat sisa-sisa bahan-bahan yang menjijikkan dan diragui kesuciannya. ${ }^{61}$ Maka, perkara ini menjadi kerisauan ibu bapa untuk membenarkan bahan haram masuk ke dalam tubuh badan anakanak mereka. Sebaliknya, sekiranya vaksin sememangnya diyakini terdapat unsur yang halal, maka perkara tersebut tidak menjadi penghalang untuk mevaksin anak-anak. ${ }^{62}$ Oleh sebab itu, pengkaji melihat isu keraguan terhadap halal dan haram produk vaksin menjadi argumentasi utama dalam masyarakat.

\section{Hujah 3: Vaksin dilarang dalam agama}

Terdapat sekelompok masyarakat yang menafikan vaksin sebagai salah satu kaedah perubatan pencegahan kerana perkara tersebut dilarang oleh agama mereka. Terdapat sesetengah agama bukan Islam yang mengecualikan beberapa hal ehwal keduniaan daripada diuruskan oleh manusia. Dalam kes ini, ajaran agama mereka menyatakan bahawa penyakit datang daripada tuhan. Maka, proses penyembuhan penyakit adalah urusan tuhan dan manusia tidak berhak mencampur tangan urusan tersebut. Bahkan, terdapat hujah lain yang mengatakan bahawa manusia dicipta dalam bayangan tuhan dan ini bererti manusia telah menerima sistem imuniti badan yang sempurna milik tuhan. ${ }^{63}$ Maka, tubuh badan manusia adalah suci umpama tempat peribadatan dan tidak

57 Siti Aisyah Ismail, Kontroversi Imunisasi (Jakarta Timur: Pustaka Al-Kautsar, 2014).

58 John D. Grabenstein, 'What the World's Religions Teach, Applied to Vaccines and Immune Globulins'.

59 Suhaimi (seorang anti-vax), dalam temu bual dengan penulis, 27 September 2016.

60 'Bahaya Suntikan Vaksin dan Imunisasi,' laman sesawang salah seorang yang menolak vaksin, dikemas kini 30 Januari 2011, dicapai 17 Ogos 2016, https:// mindaahad.wordpress.com/2011/01/30/bahaya-suntikan-vaksin-dan-imunisasi/.

61 'Whats Wrong with Vaccination,' laman sesawang salah seorang yang menolak vaksin.

62 Suhaimi (seorang anti-vax), dalam temu bual dengan penulis, 27 September 2016.

63 Anna Kata, 'A Postmodern Pandora's box: Anti-Vaccination Misinformation on the Internet.' 
seharusnya dinodai dengan ubat-ubatan yang berasaskan bahan-bahan asing. ${ }^{64}$ Oleh sebab itu, hujah-hujah sebegini telah menguatkan pandangan sekelompok masyarakat untuk menolak vaksin, terutamanya mereka yang berpegang teguh kepada prinsip agama masing-masing. Hal ini menunjukkan bahawa pegangan agama seseorang turut menentukan pendiriannya terhadap keputusan sama ada untuk memilih vaksin sebagai usaha pencegahan penyakit atau sebaliknya.

\section{Hujah 4: Vaksin merupakan satu teori konspirasi Barat}

Sebahagian anggota masyarakat turut menolak vaksin kerana mendakwa bahawa vaksin merupakan salah satu daripada perencanaan Barat untuk melemahkan manusia. Hal ini kerana vaksin dikatakan dapat mengawal kelahiran dan mengehadkan populasi. ${ }^{65}$ Menurut mereka lagi, pihak Barat yang menyebarkan penyakit, kemudian mereka juga yang mencipta vaksin bagi mencegah penyakit tersebut. Usaha itu adalah untuk mengaburi mata masyarakat bahawa vaksin adalah penyelamat, sedangkan mereka hanya ingin mengaut keuntungan daripada penjualan vaksin. ${ }^{66}$ Kesannya, vaksin dijadikan sebagai satu peluang untuk syarikat farmasi dan para saintis meningkatkan sumber kewangan ${ }^{67}$, lebih-lebih lagi apabila mereka ditawarkan dengan ganjaran berupa hadiah dan geran penyelidikan oleh pengusaha produk vaksin. ${ }^{68}$

Bahkan, vaksinasi dikatakan dibiayai oleh keluarga Rockefeller yang merupakan salah satu keluarga yahudi yang paling berpengaruh dan mereka terlibat dalam Zionis Internasional. Mereka juga yang mengasaskan WHO dan institusi kesihatan yang lain. Melalui hal ini, vaksinasi dikaitkan dengan satu konspirasi Zionisme yang bertujuan untuk menguasai dunia di bawah New World Order mereka. ${ }^{69}$ Oleh sebab itu, masyarakat yang ragu-ragu dengan vaksin menentang vaksinasi kerana menurut mereka, vaksinasi merupakan

${ }^{64}$ John D. Grabenstein, 'What the World's Religions Teach, Applied to Vaccines and Immune Globulins'.

65 Anna Kata, 'A Postmodern Pandora's box: Anti-Vaccination Misinformation on the Internet.'

66 'Sebab Kenapa Ustaz Ini Menolak,' laman sesawang yang menolak vaksin, dikemas kini 28 November 2015, dicapai 16 Ogos 2016, http://www.blogmazeer. com/2015/11/13-sebab-kenapa-ustaz-ini-menolak.html.

67 Anna Kata, 'A Postmodern Pandora's box: Anti-Vaccination Misinformation on the Internet.'

68 Robert M. Wolfe, Lisa K. Sharp, Martin S. Lipsky,' Content and Design Attributes of Antivaccination Web Sites'.

69 'Bahaya Suntikan Vaksin dan Imunisasi'. 
salah satu cara orang yahudi menguasai umat Islam, sekali gus melemahkan mereka dengan kesan buruk vaksinasi.

\section{Hujah 5: Pengamalan perubatan sunnah pengganti vaksin}

Terdapat ibu bapa yang menolak vaksin kerana lebih cenderung untuk mengutamakan pengamalan perubatan sunnah sebagai salah satu kaedah pencegahan. Mereka yakin bahawa mempraktikkan sunnah-sunnah Nabi SAW dalam penjagaan kesihatan adalah lebih berkesan dan menyihatkan. Antara yang dilakukan ialah pengambilan kurma dalam proses tahnik ${ }^{70}$ yang dianggap sebagai ubat sekaligus menjadi langkah pencegahan yang penting. ${ }^{71}$ Selain itu, sebahagian yang lain lebih gemar mengambil habbatu al-sauda' dan air zamzam untuk mengelakkan penyakit. ${ }^{72}$ Malahan, ada juga yang mengamalkan berbekam $^{73}$ dan pemberian susu ibu secara konsisten seperti golongan anti vaksin di Barat yang mempercayai pemberian susu ibu dapat melindungi anak-anak daripada penyakit cegahan vaksin. ${ }^{74}$

\section{PERSPEKTIF HUKUM ISLAM DALAM ISU VAKSINASI KANAK- KANAK}

Berhubung isu penerimaan masyarakat, mereka yang menolak vaksinasi lebih cenderung kepada pendapat yang mengharamkan vaksinasi. Ini kerana terdapat dakwaan bahawa penggunaan vaksin boleh memudaratkan dan menyebabkan kesan sampingan negatif, rentetan daripada pelbagai bahan kimia asing yang masuk ke dalam badan. ${ }^{75}$ Perkara ini dianggap menjadi punca kepada komplikasi penyakit yang berbahaya seperti autisme, sindrom bayi mati mengejut, sawan dan ekzema.

\footnotetext{
70 'Hujah Menolak Suntikan Imunisasi,' laman sesawang salah seorang yang menolak vaksin, dikemas kini 3 Januari 2013, dicapai 12 Ogos 2016,http://kekoh. blogspot.my/2013/01/hujah-menolak-suntikan-imunisasi.html\#!/tcmbck.

71 'Bahaya Suntikan Vaksin dan Imunisasi.

72 Suhaimi (seorang anti-vax), dalam temu bual dengan penulis, 27 September 2016.

73 'Bekam Anak Sejak Usia 25 Hari,' laman sesawang Pseudoscience Watch, dikemas kini pada 24 Mei 2016, dicapai pada 30 Mei 2016, https://www.facebook.com/ pswatch1/posts/1256448524366089.

74 Archana Chatterjee (ed.), Vaccinophobia and Vaccine Controversies of the 21st Century, 102.

75 Gregory A Poland et al., 'Vaccinology in The Third Millennium: Scientific and Social Challenges,' Current Opinion in Virology 17 (2016), 116--125.
} 
Berdasarkan sudut pandang fiqh pula, sesuatu proses pengubatan yang melanggari konsep rawatan dalam Islam serta memberi kemudaratan kepada kesihatan tubuh badan boleh dihukumkan haram. Begitu juga dengan vaksinasi. Sekiranya suntikan vaksin lebih mendatangkan kemudaratan seperti kesan sampingan yang teruk dan berpanjangan serta komplikasi penyakit lain yang serius, maka pada masa itu vaksinasi adalah diharamkan. Perkara ini adalah berdasarkan kepada firman Allah SWT:

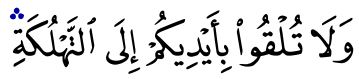

"Dan janganlah kamu sengaja mencampakkan diri kamu ke dalam bahaya kebinasaan."

(Surah al-Baqarah, 2: 195)

Bahkan, ia juga disokong oleh dalil hadis, daripada Ubadah bin Șamit, bahawa Rasulullah SAW bersabda: ${ }^{76}$

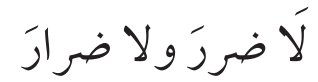

"Janganlah melakukan kemudaratan dan membalasnya dengan kemudaratan yang lain." 77

Oleh sebab itu, dalil-dalil ini menyokong pendapat bahawa vaksinasi diharamkan sekiranya mendatangkan kemudaratan kepada kanak-kanak. Begitu juga, terdapat pendapat sebahagian agamawan yang mengeluarkan fatwa pengharaman vaksinasi polio seperti yang berlaku di Pakistan, Afghanistan dan Nigeria. Pendapat ini dikeluarkan rentetan daripada dakwaan bahawa vaksinasi boleh mengakibatkan kemandulan dan akan mengurangkan jumlah umat Islam. ${ }^{78}$

Walaubagaimanapun, pengkaji berpendapatpandangan yangmengharamkan vaksinasi perlu dinilai kembali. Walaupun dalil-dalil al-Quran dan hadis yang dijelaskan menjadi sokongan kepada pandangan mereka, namun begitu, sesuatu

76 'Abd al-Raḥmān al-Suyūṭi, al-Ashbah wa al-Naẓā'ir fì Qawā'id wa Furū' alShāfi 'iyyah vol. 1 (Qāhirah: Dār al-Salām, 2011), 210.

77 Hadis riwayat Ibnu Majah, Kitab al-Aḥkām, Bab Man Banā F̄i Haqqihi Ma Yaḍurru Bijārihi, no. hadis 2340. Lihat Șāliḥ Ibn 'Abd al-'Azīz, Mawsū'ah alHadīth al-Sharīf, al-Kutub al-Sittah (Riyāḍ: Maktabah Dār al-Salām, 2008), 2617.

78 'Kumpulan Islam Selar Fatwa Anti Vaksin Polio,' laman sesawang Al-Arabiya, dikemaskini 27 Februari 2014, dicapai 15 September 2016, http://english. alarabiya.net/en/News/middle-east/2014/02/27/Islamic-group-criticizes-fatwasagainst-polio-vaccines.html. 
hukum yang dikeluarkan perlu juga melihat kepada realiti keadaan vaksinasi yang sebenar. Adakah benar vaksinasi mendatangkan kesan sampingan yang memudaratkan? Ini kerana vaksinasi memang terbukti melalui kajian saintifik mampu mencegah penyakit cegahan vaksin. Buktinya, kajian daripada WHO menunjukkan bahawa kejayaan program imunisasi telah menyelamatkan dua hingga 5 juta nyawa setiap tahun, bahkan mengelakkan kesakitan dan kematian ribuan manusia. ${ }^{79}$ Perbandingan kebaikan dan keburukan vaksinasi ini akan dibincangkan lagi dalam perbincangan selanjutnya. Oleh sebab itu, pengkaji mendapati bahawa pandangan yang dinyatakan oleh agamawan di tiga negara sebelum ini, iaitu Pakistan, Afghanistan, dan Nigeria adalah tidak didasari oleh kajian yang benar-benar boleh menyokong hujah mereka. Oleh sebab itu, hujah tersebut adalah lemah kerana lebih berlandaskan persepsi 'anti-barat' dan bukan berdasarkan bukti yang kukuh.

Selain itu, menyentuh isu pengharaman vaksinasi, 'Abd al-'Azīz bin Bāz dalam fatwanya turut menyebut bahawa vaksinasi yang mendatangkan kesan sampingan yang lebih besar dan serius adalah diharamkan. ${ }^{80}$ Namun begitu, pendapat yang dikemukakan oleh 'Abd al-'Azīz bin Bāz ini hanyalah sekadar teori yang menjelaskan perubahan hukum harus kepada haram proses vaksinasi. Ini kerana beliau sendiri menyokong usaha vaksinasi yang dilakukan pada hari ini memandangkan manfaat yang diperoleh adalah lebih besar berbanding kesan sampingan akibat suntikan vaksin yang minimum.

Oleh yang demikian, sebagai menguatkan hujah bahawa vaksinasi memberikan kebaikan dan pendapat yang mengharamkan vaksinasi adalah dilihat bercanggah dengan realiti sebenar, maka penilaian hukum vaksinasi turut diteliti melalui analisis terhadap kesan sampingan serta risiko pengabaian vaksin. Walaupun kemudaratan tersebut sememangnya wujud iaitu kesan sampingan selepas suntikan vaksin seperti kesan bengkak, kemerah-merahan, sengal dan demam, namun begitu, kesan-kesan itu hanyalah dalam kadar yang minimum. Sebaliknya, jika dibandingkan dengan tindakan mengabaikan pengambilan vaksin, risikonya adalah jauh lebih besar. Pengabaian vaksinasi boleh menyebabkan pelbagai komplikasi penyakit yang lebih sukar untuk diubati. Oleh sebab itu, pengkaji melihat bahawa vaksinasi lebih memberi kebaikan berbanding kemudaratan, justeru hukum haram tidak sewajarnya disandarkan terus kepada vaksinasi tanpa menilai pertimbangan kesan

79 Margaret Chan, 'Beyond Expectations: 40 Years of EPI,' The Lancet 383 (2014), 1697-1698.

80 'Hukum Vaksin Kanak-Kanak sebagai Imuniti,' laman sesawang Islam QA, dikemaskini 11 Mac 2003, dicapai 15 September 2016, https://islamqa.info/ $\operatorname{ar} / 20276$ 
sampingan dan risiko sekiranya kanak-kanak tidak divaksin. Bahkan, pandangan mengenai kegusaran terhadap vaksin itu sebenarnya lebih bersifat sekadar andaian tanpa disertakan fakta, bukti yang kukuh atau testimoni yang sebenar. ${ }^{81}$

Rentetan itu, pengkaji lebih cenderung kepada pandangan yang mengharuskan vaksinasi. Hukum keharusan vaksinasi didasari berdasarkan beberapa dalil dan hujah sokongan seperti berikut. Antaranya ialah beberapa ayat al-Quran yang menjelaskan anjuran berubat dan menjaga kesihatan. Firman Allah SWT:

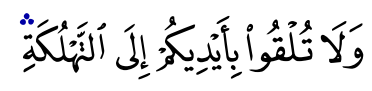

"Dan janganlah kamu sengaja mencampakkan diri kamu ke dalam bahaya kebinasaan.”

(Surah al-Baqarah, 2: 195)

Ayat ini menjelaskan bahawa Allah SWT menegah manusia daripada terjerumus ke dalam apa-apa perkara yang boleh memudaratkan kehidupan manusia, termasuklah kemudaratan penyakit yang boleh mencacatkan kelangsungan kehidupan seperti beberapa penyakit cegahan vaksin iaitu difteria, polio, demam campak dan tibi. Oleh sebab itu, mengambil langkah pencegahan menerusi suntikan vaksin merupakan salah satu usaha yang dapat mengelakkan diri daripada kebinasaan seperti yang dinyatakan dalam nas.

Hukum harus berubat turut disokong oleh beberapa dalil al-Sunnah berkenaan galakan berubat dan ikhtiar mencari kesembuhan daripada Allah SWT. Hal ini selaras dengan hakikat bahawa penyakit dan penawar itu adalah datang daripada Allah SWT, justeru dalam urusan tersebut, manusia seharusnya berusaha dan kemudiannya bertawakkal kepada Allah SWT. Antaranya ialah hadis daripada Usamah bin Syuraih bahawa Rasulullah SAW bersabda:

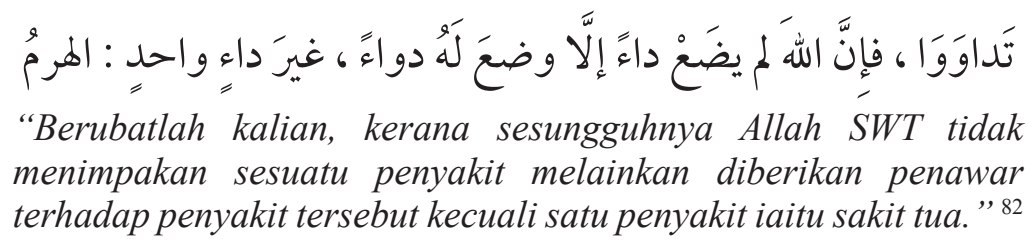

Dalil seterusnya, daripada Jabir, Rasulullah SAW bersabda:

\footnotetext{
81 Zulkifli Mohamad al-Bakri (Mufti Wilayah Persekutuan Kuala Lumpur), dalam temu bual dengan penulis, 9 Ogos 2016.

82 Hadis riwayat Abi Daud, Kitab al-Ṭibb, Bab al-Rajul Yatadāwā, no. hadis 3855. Lihat Șālih Ibn 'Abd al-'Azīz, Mawsū'ah al-Hadīth al-Sharīf, al-Kutub al-Sittah, 1507.
} 


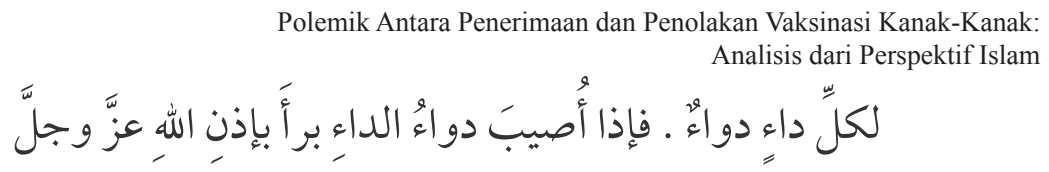

"Setiap penyakit pasti ada ubatnya dan apabila sesuatu ubat diberikan terhadap sesuatu penyakit, maka penyakit tersebut akan sembuh dengan izin Allah SWT." 83

Selain itu, terdapat hadis lain yang diriwayatkan oleh Abū Hurayrah RA, Rasulullah SAW bersabda:

$$
\text { ما أنزلَ الله داءً إلَّا أنزلَ له شِفاءً }
$$

"Allah tidak menurunkan sesuatu penyakit itu melainkan Dia juga memberikan penawar bagi penyakit tersebut." 84

Ketiga-tiga dalil hadis ini menunjukkan bahawa manusia perlu berusaha mencari jalan penyembuhan, seterusnya bertawakkal kepada Allah SWT. Hal ini juga termasuklah isu vaksinasi. Suntikan vaksin yang diberikan kepada kanak-kanak merupakan suatu usaha untuk menjamin kesihatan yang baik. Hakikatnya, Allah SWT sahaja yang mampu menyelamatkan manusia daripada segala ujian berbentuk penyakit. Selain usaha mengubati penyakit, Islam sangat menekankan langkah pencegahan diri daripada penyakit. Dalil-dalil berikutnya menyokong keharusan vaksinasi sebagai perubatan pencegahan. Antaranya ialah hadis galakan memakan makanan yang boleh menjauhkan diri daripada kemudaratan sihir. Oleh sebab itu, mengambil suntikan vaksin juga diharuskan kerana dapat mengelakkan diri daripada kemudaratan penyakit. Daripada Sa'ad bin Ab̄̄ Waqqāṣ, Rasulullah SAW bersabda:

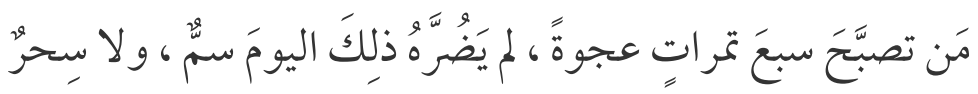

"Sesiapa yang memakan tujuh biji kurma 'Ajwah pada pagi hari, maka racun dan sihir tidak akan memudaratkannya pada hari tersebut." 85

83 Hadis riwayat Muslim, Kitab al-Salām, Bab Likulli Dā' Dawā' wa Istajāb alTadāwī, no. hadis 2204. Lihat Abū al-Ḥusayn Muslim bin al-Ḥajjaj al-Qushayrī, Sahīh Muslim (Bayrūt: Dār Ibn Hazm, 2002), 973.

84 Hadis riwayat al-Bukhari, Kitab al-Ṭibb, Bab Mā Anzala Allāh Dāan Illā Anzala lahū Syifāan, no. hadis 5678. Lihat Abū 'Abd Allāh Muḥammad bin Ismā'îl alBukhārī, Șaḥ̄ḥ al-Bukhārī, vol. 3 (Qāhirah: Maktabah al-Ṣaffā, 2003), 74.

85 Hadis riwayat al-Bukhari, Kitab al-Ṭibb, Bab al-Dawā' bi al-'Ajwah li al-Siḥri, no. hadis 5769 dan Abū Daud, Kitab al-Tibb, Bab Fī Tamarah al-'Ajwah, no hadis 3876. Lihat Abū 'Abd Allāh Muḥammad bin Isma'īl al-Bukhāri, Șaḥịh al-Bukhārī, vol. 3, 92; Șāliḥ Ibn 'Abd al-'Azīz, Mawsū'ah al-Hadìth al-Sharîf, al-Kutub alSittah, 1508. 
Begitu juga, tuntutan untuk mencegah diri daripada wabak penyakit disarankan oleh Rasulullah SAW melalui larangan mendekati kawasan yang telah tersebar wabak penyakit bagi mengelakkan jangkitan penyakit tersebut berpindah kepada orang yang sihat. ${ }^{86}$ Daripada Usamah bin Zaid daripada Sa'ad, Rasulullah SAW bersabda:

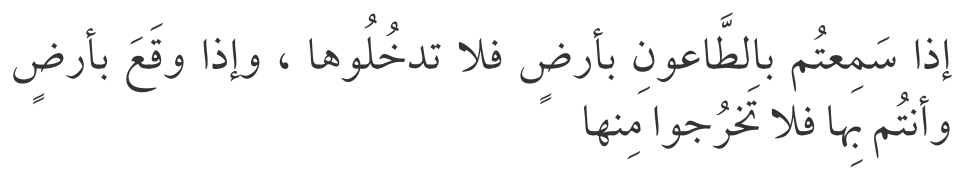

"Jika kalian mendengar tentang wabak penyakit taun di sesuatu tempat, maka janganlah kalian memasuki tempat tersebut. Sekiranya wabak penyakit tersebut terkena di sesuatu tempat dan kalian sedang berada di tempat itu, maka janganlah kalian keluar dari kawasan tersebut." 87

Bahkan, dalam beberapa keadaan bagi kes penyakit berjangkit, si pesakit akan dikuarantin iaitu diasingkan daripada orang ramai bagi mengelakkan penyebaran penyakit tersebut berlaku secara berleluasa. Begitu juga, apabila seseorang dijangkiti penyakit, dia disarankan untuk mengasingkan dirinya daripada orang lain sama ada di tempat kerja atau di tempat awam supaya penyakitnya itu tidak dipindahkan kepada orang lain yang mendekatinya. ${ }^{88}$ Perkara-perkara ini dilakukan agar tidak memudaratkan orang lain seperti mana yang terdapat dalam hadis yang diriwayatkan oleh Abū Hurayrah RA, Rasulullah SAW bersabda:

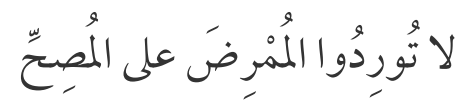

"Jangan didekatkan yang sakit dengan yang sihat." 89

Dalam hadis lain, daripada Abū Hurayrah, Rasulullah SAW bersabda:

86 Hasan Yāsīn 'Abd al-Qādir, Al-I'jāz al-Tỉbbì fì al-Kitāb wa al-Sunnah (Qāhirah: Maktabah Wahbah, 1997), 87.

87 Hadis riwayat al-Bukhari, Kitab al-Ṭibb, Bab Mā Yudhkaru fī al-Ṭā'ūn, no. hadis 5728. Lihat Abū 'Ābd Allāh Muḥammad bin Ismā'īl al-Bukhāri, Șaḥịh al-Bukhārī, vol. 3,83 .

88 Aḥmad Syauqī al-Fanjarī, Al-Tibb al-Wiqā' ‘̂ fì al-Islām (Miṣr: al-Haiah alMișriyyah al-'Ammah li al-Kitāb, 1991), 36.

89 Hadis riwayat al-Bukhari, Kitab al-Ṭibb, Bab Lā 'Adwā, no. hadis 5773. Lihat Abū 'Abd Allāh Muḥammad bin Ismā'īl al-Bukhārī, Șaḥịh al-Bukhārī, vol. 3, 93. 


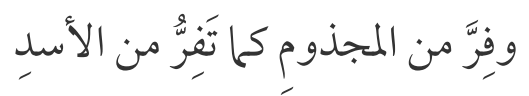

"Jauhilah orang yang terkena penyakit kusta seperti mana kamu melarikan diri daripada singa." 90

Oleh yang demikian, dalil-dalil yang telah dinyatakan menjelaskan bahawa Islam amat menitikberatkan usaha-usaha penjagaan kesihatan bukan sahaja melalui rawatan pengubatan apabila terkena penyakit, bahkan menerusi usaha-usaha pencegahan seperti vaksinasi. Apabila diamati dalil-dalil yang dijelaskan, sememangnya tiada dalil khusus berkenaan vaksinasi. Namun begitu, pendalilannya telah menunjukkan wujudnya elemen pencegahan sepertimana yang disarankan oleh Baginda SAW. ${ }^{91}$ Hal ini menyokong konsep vaksin yang telah dibuktikan secara saintifik selaras dengan konsep pencegahan yang dianjurkan dalam Islam.

Pendapat yang menyatakan keharusan vaksinasi melihat kepada kesan jangka masa panjang vaksinasi yang dapat mengelakkan jangkitan penyakitpenyakit cegahan vaksin serta manfaatnya yang besar kepada semua pihak. Tambahan pula, vaksinasi telah terbukti berkesan dan praktikal melalui ribuan kajian saintifik sebagai suatu perubatan pencegahan bagi penyakit-penyakit yang boleh dicegah oleh vaksin..$^{92}$ Bahkan, apabila dinilai daripada hukum pada masa mendatang atau al-hukmu bi al-maāl, didapati bahawa vaksinasi sememangnya sesuai untuk dilaksanakan dan ianya telah terbukti dengan pandangan daripada doktor termasuk Kementerian Kesihatan Malaysia yang menggalakkannya. ${ }^{93}$ Sokongan terhadap keharusan vaksinasi ini juga dapat

90 Hadis riwayat al-Bukhari, Kitab al-Ṭibb, Bab al-Judhām, no. hadis 5707. Lihat Abū 'Abd Allāh Muḥammad bin Ismā'īl al-Bukhārī, Șaḥ̄ḥ al-Bukhārī, vol. 3, 79.

91 Ahmad Tarmizi Mahmud (Penolong Pengarah, Bahagian Perancangan dan Penyelidikan JAKIM), dalam temu bual dengan penulis, 27 Oktober 2016.

92 Oli Angus Nnamdi et al., 'An Assessment, in Mice, of The Safety of The Childhood Immunization Vaccines Sourced from Three South-Eastern States of Nigeria,' A Trials in Vaccinology 5 (2016), 8-14.

93 Zulkifli Mohamad al-Bakri (Mufti Wilayah Persekutuan Kuala Lumpur), dalam temu bual dengan penulis, 9 Ogos 2016. 
dilihat melalui kenyataan rasmi beberapa tokoh individu negara, ${ }^{94}$ organisasi kerajaan $^{95}$ dan pelbagai entiti bukan kerajaan di Malaysia. ${ }^{96}$

Dalam konteks perbincangan semasa, beberapa fatwa telah dikemukakan oleh ulama kontemporari berkenaan dengan keharusan vaksinasi terhadap kanak-kanak. Antaranya ialah fatwa daripada ulama antarabangsa seperti 'Ali Jum'ah ${ }^{97}$ yang merupakan Mufti Besar Mesir, ulama Afrika, ${ }^{98}$ Majma’ Fiqh Islami $^{99}$ dan Deklarasi Islamabad ${ }^{100}$ berkenaan fatwa vaksin polio. Seterusnya, fatwa di peringkat nasional seperti fatwa JAKIM, fatwa negeri Terengganu dan fatwa Wilayah Persekutuan juga mengharuskan imunisasi melalui proses

94 Kenyataan Perdana Menteri Dato' Seri Najib Tun Abdul Razak, https://www. najibrazak.com/bm/blog/vaksin-dan-imunisasi/. Lihat juga kenyataan Tun Siti Hasmah, http://www.bernama.com/bernama/v8/bm/ge/newsgeneral. php?id=1184306. Lihat juga kenyataan pakar Professor Datuk Dr Abd Rahim Mohamad, http://www.nst.com.my/news/2016/06/154190/experts-blast-antivaccinists? $\mathrm{m}=1$

95 Kenyataan Media Kementerian Wanita dan Pembangunan Keluarga: Isu Wabak Difteria dan Antivaksin, https://www.facebook.com/kpwkm/photos/a.427272221 789.212150.120357611789/10153537521676790/?type=3\&theater

96 Kenyataan Media Persatuan Perubatan Islam Malaysia / Islamic Medical Association Of Malaysia (IMAM) berkenaan vaksinasi, https://www. facebook.com/imamalaysia/posts/1226432304063704. Lihat juga Kenyataan Rasmi I-Medik dalam Isu Vaksin, https://www.facebook.com/imedikpusat/ posts/1126436804088888. Lihat juga Kenyataan Media Persatuan Pakar-Pakar Perubatan Keluarga Malaysia (FMSA) mengenai Isu Vaksin, https://www. facebook.com/FMSA.Malaysia/posts/1128538033874559:0.

97 Fatwa Ulama Mesir, 'Hukum Vaksin bagi Mencegah Kecacatan Anggota pada Kanak-Kanak,' laman sesawang Dar al-Ifta' al-Misriyyah, dikemas kini 11 September 2004, dicapai 15 September 2016, http://www.dar-alifta.org/AR/ ViewFatwa.aspx?ID=3586\&text=\%D8\%A7\%D9\%84\%D8\%AA\%D8\%B7\%D8 \%B9\%D9\%8A\%D9\%85\&MoftiIds=.

98 Fatwa Ulama Afrika, 'Memahami Vaksin dan Kepentingannya,' laman sesawang Union of African Muslim Scholars, dikemas kini 3 Mac 2016, dicapai 15 September 2016, http://africanulama.org/blog/2016/03/03/343/.

99 Fatwa daripada Majma' Fiqh al-Islam al-Duwali, 'Galakan Vaksinasi bagi Mengelakkan Kecacatan Anggota pada Kanak-Kanak, laman sesawang International Islamic Fiqh Academy, dikemas kini 9 Ogos 2009, dicapai 15 September 2016, http://www.iifa-aifi.org/2647.html.

100 Fatwa Deklarasi Islamabad, 'International Ulama Conference on Polio Eradication,' bertarikh 15-16 Jun 2014, http://www.endpolio.com.pk/beta/images/ reports/English-Declaration.pdf. 
vaksinasi terhadap kanak-kanak. ${ }^{101}$ Semua fatwa ini menyokong keharusan vaksinasi kerana vaksin terbukti sebagai perisai yang boleh melindungi kanak-kanak daripada penyakit yang boleh memberi kemudaratan lain seperti komplikasi penyakit yang lebih serius dan kecacatan pada anggota badan.

\section{PENUTUP}

Tuntasnya, vaksin adalah harus digunakan selagi mana tiada sumber haram dan meragukan ketika proses penghasilan vaksin dijalankan. Sekiranya tiada pilihan atau alternatif lain, sumber yang haram tadi boleh menjadi harus kerana melihat kepada kemaslahatan yang lebih besar iaitu untuk memelihara agama. Walau bagaimanapun, penggunaan vaksin terhadap kanak-kanak di Malaysia telah dinyatakan harus dan tiada unsur bahan yang meragukan dalam produk vaksin.

Selain itu, walaupun kesan sampingan turut berlaku akibat daripada pengambilan vaksin, namun begitu kesan sampingan yang wujud adalah bersifat minor sahaja. Bahkan, risiko penyakit yang akan menimpa seseorang jika dia tidak mendapatkan rawatan perubatan vaksinasi adalah lebih memudaratkan. Oleh sebab itu, pelaksanaan vaksinasi diharuskan kerana menepati konsep rawatan pencegahan yang dianjurkan oleh agama. Bahkan, vaksinasi turut memenuhi prinsip objektif syarak yang utama, iaitu mendatangkan kemaslahatan dan menolak kemudaratan.

Melihat kepada pentingnya vaksinasi kepada kanak-kanak memandangkan sistem ketahanan badan mereka masih memerlukan penjagaan menyeluruh, justeru ibu bapa sangat berperanan memastikan keputusan terbaik buat anakanak mereka. Program Imunisasi Kebangsaan (NIP) sangat menitikberatkan partipasi dan dokongan ibu bapa bagi memastikan liputan imunisasi yang menyeluruh di Malaysia. Walaupun masih terdapat cabaran, kekangan dan pelbagai aspek yang perlu diambil kira oleh kerajaan dalam usaha memandatorikan program ini, namun begitu, pengkaji berpendapat, kerajaan

101 Fatwa JAKIM, 'Soalan Lazim Mengenai Vaksin dan Imunisasi,' dikemas kini Julai 2015, dicapai 19 September 2016, http://www.moh.gov.my. Lihat juga Fatwa Terengganu, 'Wajib Lindungi Kanak-Kanak Melalui Vaksin,' laman sesawang Mstar, dikemas kini 5 Julai 2016, dicapai 19 September 2016, http://www. mstar.com.my/berita/berita-semasa/2016/07/05/wajib-lindungi-kanak-kanakvaksin/. Lihat juga Fatwa WP Kuala Lumpur, 'Mufti Hukum Suntikan Vaksin Adalah harus,' laman sesawang Sinar Harian, dikemas kini 23 Jun 2016, dicapai 12 November 2016, http://www.sinarharian.com.my/nasional/mufti-hukumsuntikan-vaksin-adalah-harus-1.535623. 
wajar meneliti kembali dan memperkemas dasar program NIP yang sedia ada menerusi usaha dan tindakan yang menyeluruh demi mencapai matlamat rakyat Malaysia bebas daripada penyakit cegahan vaksin.

\section{RUJUKAN}

'Abd al-Raḥmān al-Suyūṭi, al-Ashbah wa al-Nazā ’ir fì Qawā 'id wa Furū' alShāfi 'iyyah, vol. 1 (Qāhirah: Dār al-Salām, 2011).

Abū 'Abd Allāh Muhammad bin Ismā'īl al-Bukhārī, Saḥ̄ḥ al-Bukhārī, vol. 3 (Qāhirah: Maktabah al-Șaffā, 2003).

Abū al-Husayn Muslim bin al-Hajjaj al-Qushayrī, Șaḥịh Muslim (Bayrūt: Dār Ibn Hazm, 2002).

Aḥmad Syauqī al-Fanjarī, Al-Tỉbb al-Wiqā 'î fì al-Islām, (Miṣr: al-Haiah alMișriyyah al-'Ammah li al-Kitāb, 1991.

Anna Kata, 'A Postmodern Pandora's box: Anti-Vaccination Misinformation on the Internet,' Vaccine 28/7 (2010): 1709-1716.

Anna Kata, 'Anti-Vaccine Activists, Web 2.0, and The Postmodern Paradigm: An Overview of Tactics and Tropes Used Online by The Anti-Vaccination Movement,' Vaccine 30/25 (2012): 3778-3789.

Anti Vaksin, https:/www.facebook.com/ain.naurah/ posts/10208462951397026. 23 Oktober 2015.

Archana Chatterjee (ed.), Vaccinophobia and Vaccine Controversies of the 21st Century (New York: Springer Science Bussiness Media, 2013).

Bahagian Pendidikan Kesihatan, Kementerian Kesihatan Malaysia, 'Fakta Imunisasi Kanak-Kanak Bagi Kakitangan Kesihatan,' 10, http:// www.infosihat.gov.my/infosihat/media/garis_panduan/_ I/pdf/03 imunisasiKanak_BM.pdf.

Bahaya Suntikan Vaksin dan Imunisasi, https://mindaahad.wordpress. com/2011/01/30/bahaya-suntikan-vaksin-dan-imunisasi/. 30 Januari 2011.

Bekam Anak Sejak Usia 25 Hari, https://www.facebook.com/pswatch1/ posts/1256448524366089. 24 Mei 2016.

Carmen Liliana Barbacariu, 'Parents' Refusal to Vaccinate Their Children: An Increasing Social Phenomenon Which Threatens Public Health,' Procedia - Social and Behavioral Sciences 149 (2014), 84-91.

Clinical Practice Guidelines: Childhood Immunisation, Ministry of Health Malaysia and Academy of Medicine, (MOH/P/PAK/81.04 (GU) (2004), 1, http://www.moh.gov.my/attachments/3934.pdf. 
Elakkan Imunisasi, http://zullgp.blogspot.my/2012/11/elakkan-suntikanimunisasi.html. 4 November 2012.

Fatima Riaz \& Yasir Waheed, 'Islam dan Polio,' The Lancet Infectious Disease, 14/9 (September 2014), 791-792.

Fatwa Deklarasi Islamabad, 'International Ulama Conference on Polio Eradication,' bertarikh 15-16 Jun 2014, http:/www.endpolio.com.pk/ beta/images/reports/English-Declaration.pdf.

Fatwa JAKIM, 'Soalan Lazim Mengenai Vaksin dan Imunisasi,' http://www. moh.gov.my. Julai 2015.

Fatwa Majma' Fiqh al-Islam al-Duwali, 'Galakan Vaksinasi bagi Mengelakkan Kecacatan Anggota pada Kanak-Kanak,' http://www.iifa-aifi.org/2647. html. 9 Ogos 2009.

Fatwa Terengganu, 'Wajib Lindungi Kanak-Kanak Melalui Vaksin,' http:// www.mstar.com.my/berita/berita-semasa/2016/07/05/wajib-lindungi-kanakkanak-vaksin/. 5 Julai 2016.

Fatwa Ulama Afrika, 'Memahami Vaksin dan Kepentingannya,' http:// africanulama.org/blog/2016/03/03/343/. 3 Mac 2016.

Fatwa Ulama Mesir, 'Hukum Vaksin bagi Mencegah Kecacatan Anggota pada Kanak-Kanak,' http://www.dar-alifta.org/AR/ViewFatwa.aspx?ID=35 86\&text $=\%$ D8\%A7\%D9\%84\%D8\%AA \%D8\%B7\%D8\%B9\%D9\%8A $\%$ D9\%85\&MoftiIds=. 11 September 2004.

Golongan Anti-Vaksin Menjerat Anak, http://www.utusan.com.my/gayahidup/kesihatan/golongan-antivaksin-menjerat-anak-1.122355. 9 Ogos 2015.

Gregory A Poland et al., 'Vaccinology in The Third Millennium: Scientific and Social Challenges,' Current Opinion in Virology 17 (2016), 116-125.

Hasan Yāsīn 'Abd al-Qādir, Al-I'jāz al-Tỉbbī fì al-Kitāb wa al-Sunnah, Qāhirah: Maktabah Wahbah, 1997.

Hujah Menolak Suntikan Imunisasi, http://kekoh.blogspot.my/2013/01/hujahmenolak-suntikan-imunisasi.html\#!/tcmbck. 3 Januari 2013.

Hukum Vaksin Kanak-Kanak sebagai Imuniti, https://islamqa.info/ar/20276. 11 Mac 2003.

Immunise4life Expert Coalition, Immunise4life Booklet, Selangor: Ultra Work Coomunications, www.immunise4life.my/resources/IFL-BookletEnglish-Web.pdf.

Irwan Mohd Subri, 'Pencegahan Penyakit Melalui Kaedah Pelalian Menurut Perspektif Islam,' 'Ulum Islamiyyah Journal 17 (2016), 57-77. 
John D. Grabenstein, 'What the World's Religions Teach, Applied to Vaccines and Immune Globulins'.

Julie Leask and Peter McIntyre, 'Public Opponents of Vaccination: A Case Study,' Vaccine, 21/32 (2003), 4700-4703.

Julie Leask et al., 'What Maintains Parental Support for Vaccination When Challenged by Anti-Vaccination Messages? A Qualitative Study,' Vaccine, 24/49-50 (2006), 7238-7245.

Katrina F. Brown, 'UK parents' decision-making about measles-mumpsrubella (MMR) vaccine 10 years after the MMR-autism controversy: A qualitative analysis,' Vaccine, 30/10 (2012) 1855- 1864.

Kementerian Kesihatan Jamin Vaksin di Malaysia Halal, http://www.mstar. com.my/berita/berita-semasa/2015/10/29/kementerian-kesihatanjamin-vaksin-di-malaysia-halal/. 29 Oktober 2015.

Kenyataan Akhbar KPK 5 Jan 2016: Kes Difteria di Malaysia, http:// kpkesihatan.com/2016/01/05/kenyataan-akhbar-kpk-5-jan-2016-kesdifteria-di-malaysia. 5 Januari 2016.

Kenyataan Media Kementerian Wanita dan Pembangunan Keluarga: Isu Wabak Difteria dan Antivaksin, https://www.facebook.com/kpwkm/ photos/a.427272221789.212150.120357611789/10153537521676790/? type $=3 \&$ theater

Kenyataan Media Persatuan Pakar-Pakar Perubatan Keluarga Malaysia (FMSA) mengenai Isu Vaksin, https://www.facebook.com/FMSA.Malaysia/ posts/1128538033874559:0.

Kenyataan Media Persatuan Perubatan Islam Malaysia / Islamic Medical Association Of Malaysia (IMAM) berkenaan vaksinasi, https://www. facebook.com/imamalaysia/posts/1226432304063704.

Kenyataan pakar Professor Datuk Dr Abd Rahim Mohamad, http://www.nst. com.my/news/2016/06/154190/experts-blast-anti-vaccinists?m=1

Kenyataan Perdana Menteri Dato' Seri Najib Tun Abdul Razak, https://www. najibrazak.com/bm/blog/vaksin-dan-imunisasi/.

Kenyataan Rasmi I-Medik dalam Isu Vaksin, https:/www.facebook.com/ imedikpusat/posts/1126436804088888.

Kenyataan Tun Siti Hasmah, http://www.bernama.com/bernama/v8/bm/ge/ newsgeneral.php?id=1184306.

Khoo Yoon Khean, Gerakan Anti-Vaksin Keliru Fakta Sebenar, http://www. mmgazette.com/gerakan-anti-vaksin-keliru-fakta-sebenar-dr-khooyoong-khean. 5 Disember 2013. 
Kumpulan Islam Selar Fatwa Anti Vaksin Polio, http://english.alarabiya. net/en/News/middle-east/2014/02/27/Islamic-group-criticizes-fatwasagainst-polio-vaccines.html. 27 Februari 2014.

Laman Facebook, https:/www.facebook.com/ain.naurah/ posts/10207253217034423. 22 Mei 2015.

Margaret Chan, 'Beyond Expectations: 40 Years of EPI,' The Lancet 383 (2014), 1697-1698.

National Pharmacy News: Immunisation for The Good of All, http:/www. mps.org.my/newsmaster.cfm?\&menuid=36\&action=view\&retrieve id=196. 26 Mei 2002.

Oli Angus Nnamdi et al., 'An Assessment, in Mice, of The Safety of The Childhood Immunization Vaccines Sourced from Three South-Eastern States of Nigeria',' A Trials in Vaccinology 5 (2016), 8-14.

Philip D. Minor, 'Live Attenuated Vaccines: Historical Successes and Current Challenges,' Virology 479-480 (2015), 379-392.

Pieter H. Streefland, 'Public Doubts About Vaccination Safety and Resistance Against Vaccination,' Health Policy, 55/3 (2001) 159-172.

Pieter Streefland, A.M.R. Chowdhury, Pilar Ramos-Jimenez, 'Patterns of Vaccination Acceptance,' Social Science and Medicine, 49/12 (1999): 1705-1716.

Robert M. Wolfe, Lisa K. Sharp, 'AntiVaccinationists Past and Present,' BMJ, 325/7361 (2002), 430-432.

Robert M. Wolfe, Lisa K. Sharp, Martin S. Lipsky,' 'Content and Design Attributes of Antivaccination Web Sites,' JAMA, 287/24 (2002): 32453248.

Șālih Ibn 'Abd al-'Azīz, Mawsū'ah al-Hadīth al-Sharīf, al-Kutub al-Sittah (Riyāạ: Maktabah Dār al-Salām, 2008).

Sebab Kenapa Ustaz Ini Menolak, http://www.blogmazeer.com/2015/11/13sebab-kenapa-ustaz-ini-menolak.html. 28 November 2015.

Siti Aisyah Ismail, Kontroversi Imunisasi (Jakarta Timur: Pustaka Al-Kautsar, 2014).

Soalan Lazim Mengenai Vaksin dan Imunisasi, http://www.moh.gov.my. Julai 2015.

Suhazeli Abdullah, Vaksin untuk Bayi Anda: Mitos vs Realiti (Kelantan: Koperasi Amal Medik Malaysia Bhd., 2014). 
Susanna Esposito et al., 'Vaccine-Preventable Diseases: From Paediatric to Adult Targets,' European Journal of Internal Medicine, 25/3 (2014): 203-212.

Tiada DNA Babi: KKM Jamin Semua Vaksin di Malaysia Halal, http:/www. mynewshub.cc/2015/11/02/tiada-dna-babi-kkm-jamin-semua-vaksindi-malaysia-halal. 2 November 2015.

Vaksin Halal: Rakyat Diminta Tidak Ragu-Ragu Ambil Suntikan Imunisasi, http://www.astroawani.com/berita-malaysia/vaksin-halal-rakyatdiminta-tidak-ragu-ragu-ambil-suntikan-imunisasi-110703. 11 Julai 2016.

Whats Wrong with Vaccination, http://ourkizuna.blogspot.my/2013/09/whatswrong-with-vaccination.html. 23 Disember 2013.

\section{Temu bual}

Afiq Izzudin A Rahim (Pegawai Perubatan dan Kesihatan, Klinik Kesihatan Badang, Kota Bharu, Kelantan), dalam temu bual dengan penulis melalui emel, 3 Ogos 2016.

Ahmad Tarmizi Mahmud (Penolong Pengarah, Bahagian Perancangan dan Penyelidikan JAKIM), dalam temu bual dengan penulis, 27 Oktober 2016.

Suhaimi (seorang anti-vax), dalam temu bual dengan penulis, 27 September 2016.

Zulkifli Mohamad al-Bakri (Mufti Wilayah Persekutuan Kuala Lumpur), dalam temu bual dengan penulis, 9 Ogos 2016. 